\title{
EFFECTS OF AUXIN POLAR TRANSPORT INHIBITORS ON THE GROWTH OF THE EXCISED FOURTH INTERNODE IN TULIPS
}

\author{
Elżbieta WĘGRZYNOWICZ-LESIAK ${ }^{1}$, Justyna GÓRAJ ${ }^{1}$, Kensuke MIYAMOTO², \\ Junichi UEDA ${ }^{3}$, Marian SANIEWSKI*1 \\ ${ }^{1}$ Research Institute of Horticulture, Konstytucji 3 Maja 1/3, 96-100 Skierniewice, Poland \\ ${ }^{2}$ Faculty of Liberal Arts and Sciences, Osaka Prefecture University, \\ 1-1 Gakuen-cho, Naka-ku, Sakai, Osaka 599-8531, Japan \\ ${ }^{3}$ Graduate School of Science, Osaka Prefecture University, \\ 1-1 Gakuen-cho, Naka-ku, Sakai, Osaka 599-8531, Japan
}

Received: November 22, 2013; Accepted: December 8, 2013

\begin{abstract}
Effects of auxin polar transport inhibitors: methyl 2-chloro-9-hydroxyfluorene-9-carboxylate (morphactin IT 3456), 2,3,5-triiodobenzoic acid (TIBA) and $N$-1-naphthylphthalamic acid (NPA) on elongation growth of the excised fourth internode of tulips (Tulipa gesneriana L.) cv. Apeldoorn were studied. After removal of flower bud, the continuing elongation of the excised fourth internode kept in water in normal or inverted position was observed, the elongation in inverted position being significantly higher than that in the normal position. On the other hand, the application of these inhibitors $(0.2 \%, \mathrm{w} / \mathrm{w}$ in lanolin) in the place of removed flower bud substantially enhanced the elongation, the stimulation being much higher in the normal position than in the inverted one. When the inhibitors were applied in the middle or $1 \mathrm{~cm}$ from the base of the internode, the growth-promoting effect of these inhibitors was observed both in the upper and lower part of the internode, being greater in the upper part of the internode, regardless of the position of explants. Simultaneous application of indole-3-acetic acid (IAA) $(0.1 \%, \mathrm{w} / \mathrm{w}$ in lanolin) at the place of the removed flower bud in the normal position with morphactin, TIBA and NPA applied in the middle or $1 \mathrm{~cm}$ from the base of the excised internode greatly stimulated the elongation, whereas almost no growthpromoting effect of these inhibitors was observed, in comparison to IAA. On the contrary, when IAA was applied on the base of the excised internode in the inverted position, the growth was inhibited, compared to that with lanolin only. The inhibitory effect of auxin was eliminated by the simultaneous application of morphactin, TIBA and NPA placed in the middle of the excised internode. These results suggest that auxin levels in the excised internode regulated by auxin polar transport play a crucial role in the regulation of its elongation growth.
\end{abstract}

Key words: auxin polar transport inhibitors, indole-3-acetic acid, methyl 2-chloro-9-hydroxyfluorene-9carboxylate, $N$-1-naphthylphthalamic acid, 2,3,5-triiodobenzoic acid, tulip

\section{INTRODUCTION}

Tulip bulbs with terminal buds containing a complete flower require 12-14 weeks of low-temperature treatment for shoot elongation (De Hertogh 1974). It is well known that elongation of the stem and leaves of tulips is almost entirely due to the elongation of cells produced during earlier developmental stages of flower bud formation (Gilford \& Rees 1973). Elongation of all internodes in precooled tulip bulbs is promoted by application of auxins in the place of removed flower buds in the absence of leaves (Saniewski \& De Munk 1981; Banasik \& Saniewski 1985), supporting the idea that flower buds (gynoecium) and leaves provide auxins, 
which control the elongation growth of the stem (Op den Kelder et al. 1971; Hanks \& Rees 1977; Saniewski \& De Munk 1981; Banasik \& Saniewski 1985). Furthermore, rapid elongation of the fourth (top) internode in tulips takes place after earlier elongation of the first, the second and the third internodes (Ranwala \& Miller 2008). After removal of the flower bud in growing tulips, elongation of the fourth internode with or without leaves at different growth stages was very weak, but exogenously applied auxin (IAA, indole-3-acetic acid) to the cut surface of tulip stem resulted in substantial stimulation of elongation growth (Saniewski et al. 2010, 2012). These facts indicate that flower bud, as a source of auxin, is always necessary and responsible for elongation of the fourth internode.

To clarify the role of auxin in tulip stem growth, intensive studies using auxin polar transport inhibitors, such as morphactin (methyl 2-chloro-9hydroxyfluorene-9-carboxylate, morphac-tin IT 3456), 2,3,5-triiodobenzoic acid (TIBA) and N-1naphthylphthalamic acid (NPA), have been performed. TIBA applied at the node between the first and the second internodes of tulip flower stalk significantly inhibited the dark-induced elongation and reduced the levels of diffusible auxin from the upper internodes to the first internode (Okubo \& Uemoto 1985). Saniewski \& Okubo (1997, 1998a) found that IAA applied in the place of removed flower bud after excision of leaves promoted flower stalk elongation in the non-precooled and precooled, rooted and unrooted tulip bulbs, and TIBA applied in the middle of the fourth internode (below IAA application) significantly inhibited the growth of flower internodes. Similarly, NPA and morphactin also strongly inhibited the growth of internodes induced by IAA in precooled rooted tulip bulbs after removal of flower bud and all leaves (Saniewski \& Okubo 1998b; Saniewski et al. 1999). Morphactin also inhibited the growth of all internodes in tulips induced by flower bud in the absence of leaves. The inhibitory effects of TIBA, NPA and morphactin on tulip stem growth induced by IAA were restored by additional application of IAA treated below the place of the application of auxin transport inhibitors. These results clearly indicate that auxins produced in the flower bud play a crucial role in tulip stem growth.

Recently, we have found that the application of morphactin above the third node in decapitated tulips substantially induced the fourth internode growth (Ueda et al. 2012). It was also established that the elongation growth of the excised fourth internode in tulip shoots substantially depended on the initial length of the fourth internode (Saniewski et al. 2010). The present study was performed with an aim to clarify the role of auxin polar transport in stem growth. We report the effect of auxin polar transport inhibitors, TIBA, morphactin and NPA, and their interaction with IAA on the growth of excised fourth tulip internodes kept in water in normal and inverted positions.

\section{MATERIALS AND METHODS}

Bulbs of tulip (Tulipa gesneriana L.) cv. Apeldoorn with a circumference of $10-11 \mathrm{~cm}$, after lifting, were stored at $18-20^{\circ} \mathrm{C}$ and subsequently transferred to $5{ }^{\circ} \mathrm{C}$ for dry cooling on October 15 . The cooling period lasted from January until the beginning of March. Then the tunics were removed and the bulbs individually planted in pots and cultivated at $18-20^{\circ} \mathrm{C}$ in a greenhouse under natural light conditions.

In order to exclude the effect of other tissues, the experiments were done with the excised fourth internodes. The fourth internodes without node were detached from tulip shoots just after removal of the flower bud when the length of the fourth internode was $66 \mathrm{~mm}$ (Figs. $1 \& 3$ ), $83 \mathrm{~mm}$ (Figs. $2 \&$ 4) and $105 \mathrm{~mm}$ (Fig. 5). The excised internodes were kept in water in normal or inverted position and then treated with morphactin IT 3456, TIBA or NPA at a concentration of $0.2 \%$ (w/w in lanolin) with or without IAA at a concentration of $0.1 \%$ (w/w in lanolin) as lanolin paste. Only lanolin was applied as a control in every experiment.

In the inverted position, the excised segments were upside down. The treatments were as follows:

- the fourth internodes at the length of $66 \mathrm{~mm}$ (Fig. 1) and $83 \mathrm{~mm}$ (Fig. 2) were treated with morphactin, TIBA and NPA on the top of excised internodes in the place of removed flower 
bud (the normal position) or on the basal part (the inverted position);

- the fourth internodes at the length of $66 \mathrm{~mm}$ were treated with morphactin, TIBA and NPA in the middle of the internode and in the place of removed flower bud or on basal part with or without IAA (Fig. 3);

- the fourth internodes at the length of $83 \mathrm{~mm}$ (Fig. 4) were treated with morphactin, TIBA and NPA at $1 \mathrm{~cm}$ from the base of the internode (over water) and in the place of removed flower bud or on basal part with or without IAA;

- the fourth internodes at the length of $105 \mathrm{~mm}$ (Fig. 5) were treated with morphactin $1 \mathrm{~cm}$ from the base of the internode (over water) and in the place of removed flower buds or on basal part.

The growth of the fourth internode was measured at an interval of few days. Seven excised fourth internodes were used in each experiment. All the experiments were repeated twice. The data were subjected to the analysis of variance and Duncan's test was used to estimate the difference between means at $\mathrm{p}=0.05$.

\section{RESULTS}

After removal of the flower bud, the continuing elongation growth of the excised fourth internode of tulip shoot kept in water in normal or inverted position was observed (Figs. $1 \& 2$ ). The elongation of the excised fourth internode kept in inverted position was much higher than that kept in normal position.

The application of morphactin, TIBA or NPA in the place of removed flower bud and on the basal part of the excised fourth internode kept in water, in normal and inverted positions, substantially stimulated the elongation growth in normal position. The elongation of the fourth internode induced by these inhibitors kept in normal position was evidently higher than that in inverted position (Figs. $1 \& 2$ ).
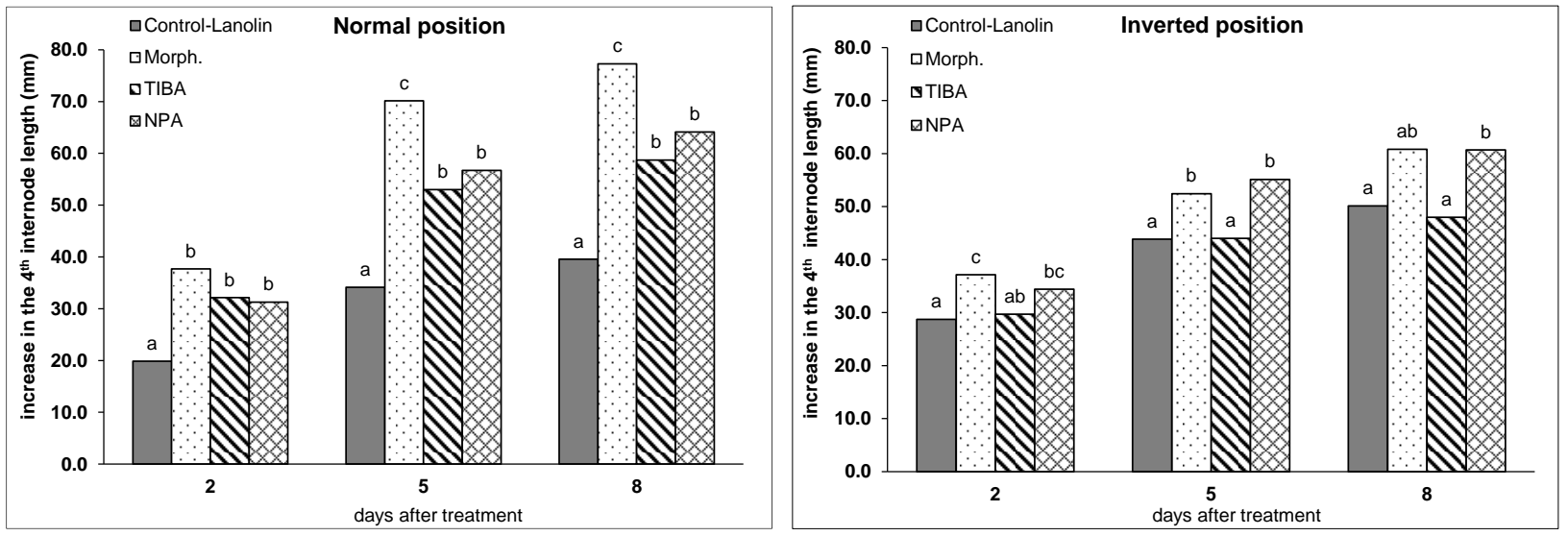

Fig. 1. Growth response of excised $4^{\text {th }}$ internodes to treatments with auxin polar transport inhibitors. Growth of the excised $4^{\text {th }}$ internode, after removal of flower bud, and kept in water in normal and inverted position and treated with morphactin (Morph.), TIBA or NPA at a concentration of $0.2 \%$ in lanolin paste on the top of the excised internode, in the place of removed flower bud or on basal part (inverted position). Initial length of the $4^{\text {th }}$ internode was $66 \pm 1.1 \mathrm{~mm}$. Means followed by the same letter are not significantly different at $\mathrm{p}=0.05 \mathrm{ac}-$ cording to Duncan's test; values are calculated separately for each day of the treatment 

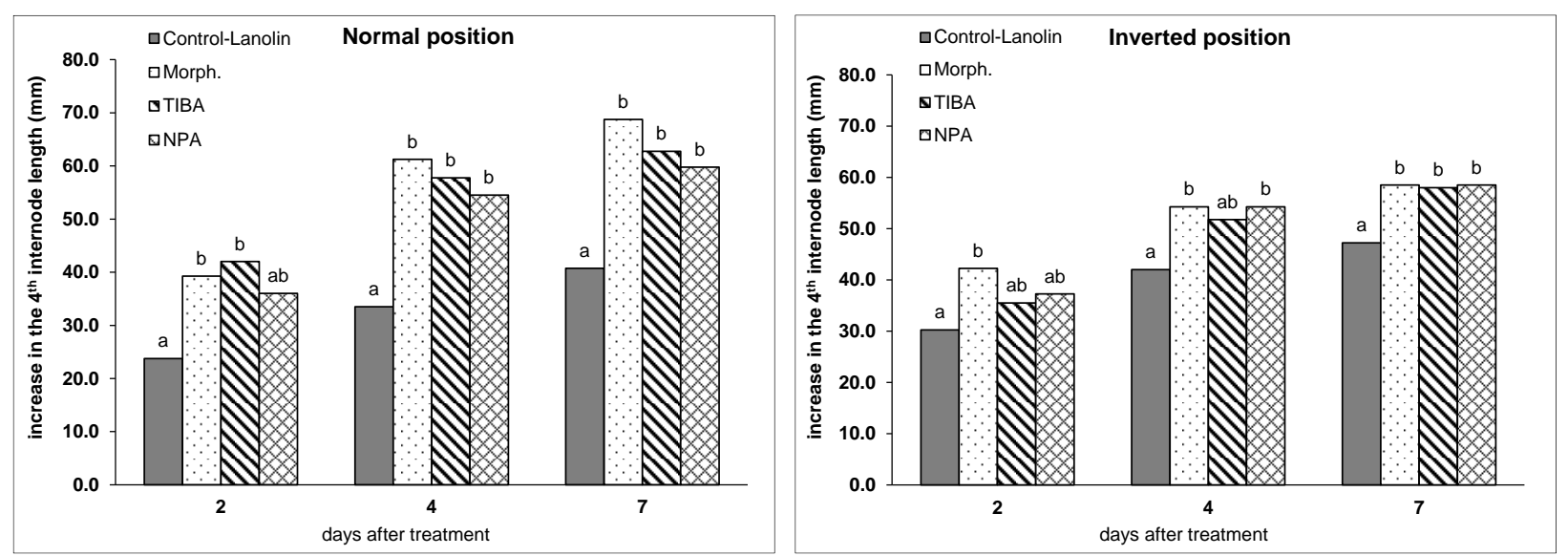

Fig. 2. Growth response of excised $4^{\text {th }}$ internodes to treatments with auxin polar transport inhibitors. Growth of the excised $4^{\text {th }}$ internode, after removal of flower bud, and kept in water in normal and inverted position and treated with morphactin (Morph.), TIBA or NPA at a concentration of $0.2 \%$ in lanolin paste on the top of the excised internode, in the place of removed flower bud or on basal part (inverted position). Initial length of the $4^{\text {th }}$ internode was $83 \pm 2.1 \mathrm{~mm}$. Means followed by the same letter are not significantly different at $\mathrm{p}=0.05 \mathrm{ac}-$ cording to Duncan's test; values are calculated separately for each day of the treatment
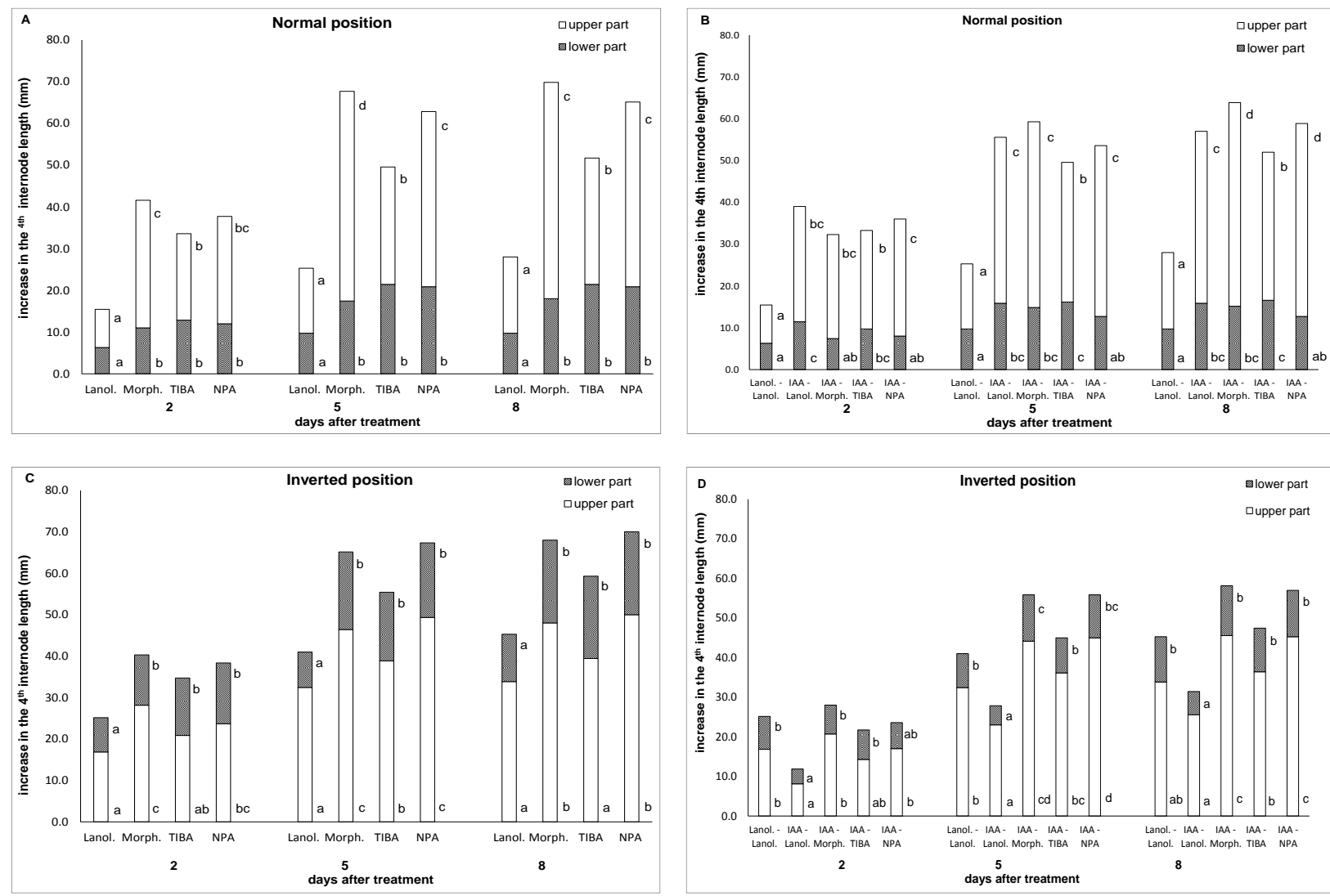

Fig. 3. Growth response of excised $4^{\text {th }}$ internodes to treatments with auxin polar transport inhibitors and IAA. Growth of the excised $4^{\text {th }}$ internode, after removal of flower bud, and kept in water in normal $(\mathrm{A}, \mathrm{C})$ and inverted (B, D) position and treated with morphactin (Morph.), TIBA or NPA at a concentration of $0.2 \%$ in lanolin paste in the middle of internode, and in the place of removed flower bud or on basal part (inverted position) was applied lanolin only or IAA at a concentration of $0.1 \%$. Initial length of the $4^{\text {th }}$ internode was $66 \pm 1.5 \mathrm{~mm}$. Means followed by the same letter are not significantly different at $\mathrm{p}=0.05$ according to Duncan's test; values are calculated separately for each day and separately below and above the treatment 

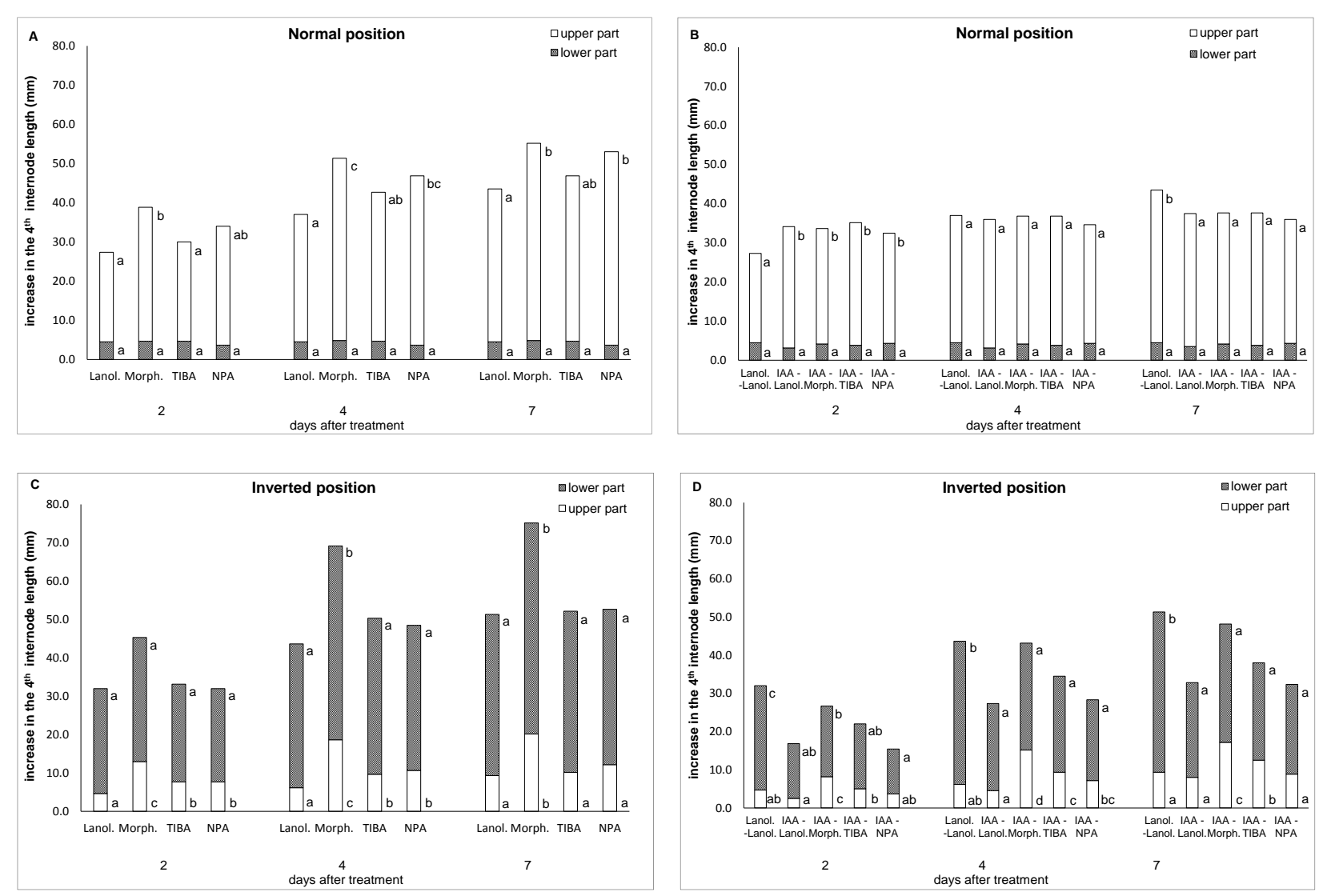

Fig. 4. Growth response of excised $4^{\text {th }}$ internodes to treatments with auxin polar transport inhibitors and IAA. Growth of the excised $4^{\text {th }}$ internode, after removal of flower bud, and kept in water in normal $(\mathrm{A}, \mathrm{C})$ and inverted (B, D) position and treated with morphactin (Morph.), TIBA or NPA at a concentration of $0.2 \%$ in lanolin paste $1 \mathrm{~cm}$ from base of the internode (over water), and in the place of removed flower bud or on basal part (inverted position) was applied lanolin only or IAA at a concentration of $0.1 \%$. Initial length of the $4^{\text {th }}$ internode was 83 $\pm 4.7 \mathrm{~mm}$. Means followed by the same letter are not significantly different at $\mathrm{p}=0.05$ according to Duncan's test; values are calculated separately for each day and separately below and above of the treatment
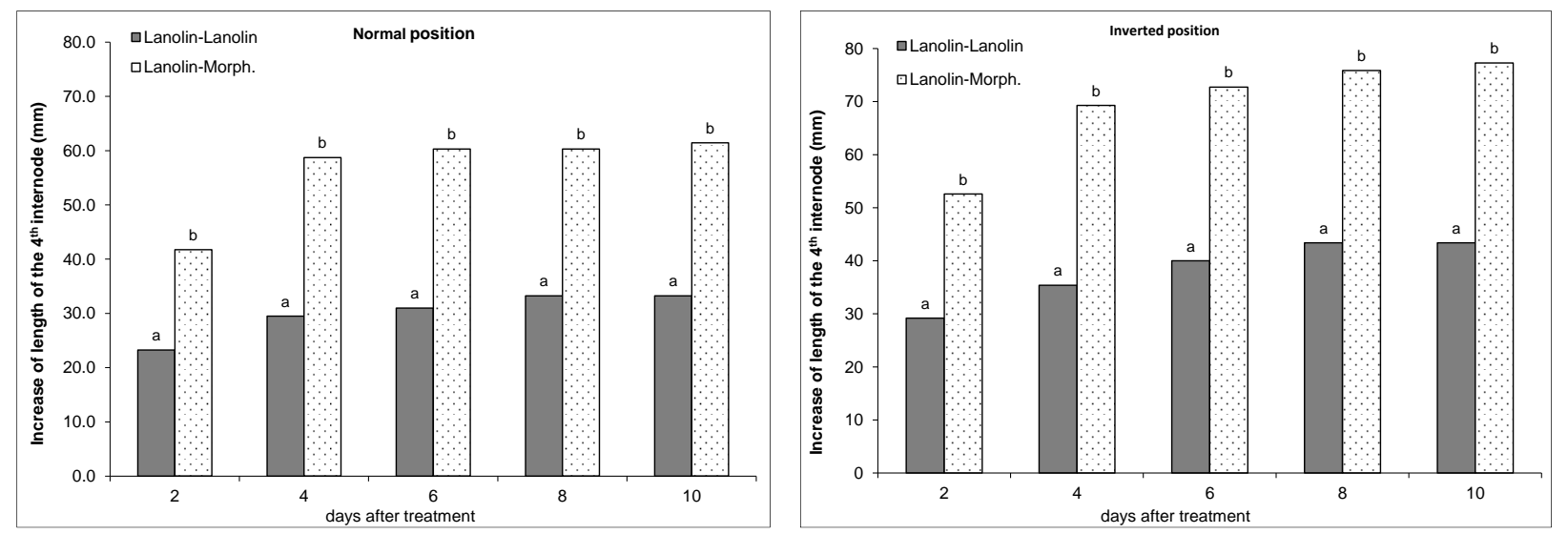

Fig. 5. Growth response of excised $4^{\text {th }}$ internode to treatments with auxin polar transport inhibitors. Growth of the excised $4^{\text {th }}$ internode, after removal of flower bud, and kept in water in normal and inverted position and treated with morphactin (Morph.) at a concentration $0.2 \%$ in lanolin paste $1 \mathrm{~cm}$ from base of internode (over water). Initial length of the $4^{\text {th }}$ internode was $105 \pm 4.3 \mathrm{~mm}$. Means followed by the same letter are not significantly different at $\mathrm{p}=0.05$ according to Duncan's test; values are calculated for all length of internode, separately for each day of the treatment 
When the excised fourth internode kept in normal and inverted positions was treated with morphactin, TIBA and NPA in the middle of the internode, the growth-promoting effect of these inhibitors was observed, both in the upper and the lower internode parts of the treatment; the effect being clearly visible in the upper part of the internode, regardless of the position of explants (Fig. 3A, C). Simultaneous application of IAA $(0.1 \%, \mathrm{w} / \mathrm{w})$ at the place of the removed flower bud in normal position with lanolin, morphactin, TIBA and NPA in the middle of the excised fourth internode greatly stimulated the growth of the explants, whereas almost no growth-promoting effect of these inhibitors was observed, in comparison to IAA treatment only (Fig. 3B).

On the contrary, when IAA was applied on the base of the excised fourth internode in inverted position, the growth of the internode was inhibited compared to that with lanolin only. The inhibitory effect of auxin was totally eliminated by the simultaneous application of morphactin, TIBA and NPA placed in the middle of the excised fourth internode (Fig. 3D).

When the excised fourth internode was kept in water in normal and inverted positions with morphactin, TIBA and NPA applied at $1 \mathrm{~cm}$ from the base of internode (over water), the growth of the internode kept in normal and inverted direction was enhanced, especially by morphactin (Figs. 4A, C \& 5). Simultaneous application of IAA on the top of the explants with morphactin, TIBA and NPA applied at $1 \mathrm{~cm}$ from the base of the internode (over water) kept in normal and inverted positions showed almost no growth-promoting effect of IAA in normal orientation (Fig. 4B). On the other hand, IAA inhibited the growth of the internode in inverted position. In this case, morphactin was effective in eliminating IAA-induced inhibition. TIBA and NPA were effective to a lesser extent (Fig. 4D).

\section{DISCUSSION}

As stated earlier, the elongation growth of the fourth internode explants was extremely small after removal of the flower bud in growing tulips, and
IAA application to the cut surface of tulip stem resulted in substantial stimulation of elongation growth. Moreover, the growth in the excised fourth internode kept in normal position depended on the initial length of the explants (Saniewski et al. 2010), which was also confirmed in the present experiments (Figs. $1 \& 2$ ).

Since auxin in the fourth internode is easily transported basipetally to lower internodes in growing tulips (Saniewski et al. 1990, 2012), the lack of endogenous auxin could cause limitation in the growth of the fourth internode. Thus, auxin produced by the flower bud is always necessary and responsible for elongation of the fourth internode. In our experiment, the growth of the excised fourth internode was affected by the position of the explants, inverted or normal. Auxin is transported mainly basipetally in tulip stems as well (Gabryszewska \& Saniewski 1983). The higher growth of the excised fourth internode kept in inverted position than in normal one could be attributed to differences in endogenous auxin flow to water; smaller amounts of auxin flow to water in inverted position.

Inhibitors of auxin polar transport, morphactin, TIBA and NPA, applied on the top of the fourth internode stimulated the growth of the internodes, regardless of the orientation of explants during the incubation, whereas the degree of stimulation of the elongation of the internode was much higher in normal position than in the inverted one (Figs. $1 \& 2$ ). In oat stem segments, treatment of auxin polar transport inhibitors such as morphactin and TIBA promoted elongation growth, this effect being interpreted as their interferences with auxin polar transport (Rapoport et al. 1978). Thus, the action of these inhibitors in tulip internode growth might also be explained by inhibition of auxin flow from the internode to the water. Auxin flow to water from internode explants kept in normal position is probably suppressed by these inhibitors, resulting in higher level of endogenous auxin responsible for elongation growth.

In further studies, it was found that TIBA applied on the scales around the basal plate to uncooled tulip bulbs cultivars Apeldoorn and Gudoshnik, before bud formation (at the beginning of July) and after flower bud formation (October and later), 
substantially stimulated the shoot growth and flowering in partially dry-cooled bulbs (Saniewski et al. 2011a, b). The growth- and flowering-promoting effect of TIBA was weaker in the fully cooled bulbs in comparison to the partially cooled bulbs. It should be mentioned that TIBA applied in the same way to the uncooled tulip bulbs did not stimulate shoot growth and flowering. These results suggest that TIBA partially replaces the cold-treatment requirement of the tulip bulbs. The mode of action of TIBA in promotion of shoot growth and flowering in partially cooled tulip bulbs has not yet been clearly explained. One possibility is that TIBA stimulated shoot growth and flowering through blocking the auxin transport from pistil and leaves to the basal plate, and finally the accumulation of auxin takes place in the tulip shoots, as was previously suggested by Geng et al. (2005a, b). McKay et al. (1994) showed that TIBA and 9-hydroxyfluorene9-carboxylic acid (HFCA) reduced both IAA level and internode elongation below their site of application in wild-type garden pea (Pisum sativum). In the short mutant $(l k b)$ which contained about two- to three-fold less free IAA than those of the wild type of garden pea, TIBA and HFCA strongly promoted the elongation of internodes and raised IAA level above the application site. Morphactin pretreatments enhanced hypocotyls elongation of Helianthus annuиs (Hasenstein \& Kaldewey 1984). Transport experiment using $5-{ }^{3} \mathrm{H}-\mathrm{IAA}$ in hypocotyl section revealed that morphactin strongly reduced the diffusible IAA. Thus, a possible mode of action of morphactin could be the blocking of auxin efflux from cells, thereby resulting in an increase of free IAA inside the cells (Hasenstein \& Kaldewey 1984). After application of morphactin above the third node of decapitated tulips, the stimulated growth of the fourth internode was clearly observed (Ueda et al. 2012). Endogenous levels of IAA in the fourth internode after the treatment of auxin polar transport inhibitors were determined using gas-liquid chromatography-mass spectrometry (GC-MS) and gas-liquid chromatography-mass spectrometry selected ion monitoring system (GC-SIM) with deuterium labeled IAA $\left(\mathrm{d}_{5}\right.$-IAA) as an internal standard. The obtained data revealed significant accumulation of IAA in the fourth internode of tulips after the treatment with morphactin. These results strongly support the opinion that stimulated growth of the fourth internode of tulips induced by auxin polar transport inhibitors is the consequence of accumulated endogenous levels of IAA, caused by blocking auxin efflux. Based on the results of this study we conclude that the appropriate level of IAA in the excised fourth internode is necessary for the elongation growth.

IAA applied on the top of the fourth internode kept in normal position stimulated the elongation growth, but inhibited that in inverted position (Figs. 3B, D \& 4D). As reported previously (Saniewski et al. 1990), when auxin was applied at higher concentrations in the place of removed flower bud after the excision of all leaves, it promoted internodal elongation less and thickening more than that at low concentrations of auxin. Auxin-induced elongation of the fourth internode was enhanced by the simultaneous treatment with silver thiosulphate, an inhibitor of ethylene action (Veen 1983; Saniewski et al. 1990). In etiolated derooted pea cuttings, the application of IAA to the hook substantially induced inhibition of elongation growth and stimulated swelling of the epicotyls. However, IAA applied to the cuttings pretreated with 1-aminooxyacetic acid, an inhibitor of ethylene biosynthesis, substantially promoted epicotyl elongation without affecting swelling (Miyamoto \& Kamisaka 1988). This may suppose that ethylene produced by endogenous auxin may somehow counteract with auxin itself in the regulation of internode growth of tulip stems.

When morphactin, TIBA and NPA were applied in the middle of the internode and IAA on the top in normal position, these inhibitors did not stimulate the growth, in comparison to IAA treatment only. On the contrary, in inverted position, inhibitors of polar auxin transport applied in the middle of the internode stimulated the elongation growth, in comparison to IAA treatment only (Fig. 3B, D). Thus, the growth-promoting effect of auxin polar transport inhibitors on the excised fourth internode might not be due to direct effect of these inhibitors, but also be caused by the inhibition of auxin-induced ethylene production, as suggested above. 
Inhibitors of polar auxin transport applied $1 \mathrm{~cm}$ from the base of the internode (over water) in normal and inverted positions showed that only morphactin stimulated the growth of the internode (Figs. 4A, C \& 5). Auxin applied on the top did not affect the growth of the fourth internode kept in normal position, but inhibited the growth in the inverted one. The inhibitors of polar auxin transport applied at the base of the internode and IAA on the top in normal position did not stimulate the growth in normal position, but the inhibitors stimulated the growth inhibited by IAA in inverted position (Fig. 4B, D). Similar interpretations as above might be possible.

In conclusion, based on the results of the elongation growth induced by the application of auxin polar transport inhibitors to the excised fourth tulip internode kept in normal and inverted positions, we assume that the physiological effects of these inhibitors depend on the direction of their applications to that of the target cells. In addition, it is possible that the action of these inhibitors might be connected with the interaction of auxin and auxin-induced ethylene. To clarify the hypothesis, further intensive studies using inhibitors of ethylene action and its biosynthesis in the excised fourth internode of tulips will be required.

\section{REFERENCES}

Banasik L., Saniewski M. 1985. The effect of different auxins on tulip stalk elongation. Acta Hort. 167: 193-204.

De Hertogh A. 1974. Principles for forcing tulips, hyacinths, daffodils, Easter lilies and Duch irises. Sci. Hortic. 2: 313-355. DOI: 10.1016/03044238(74)90041-7.

Gabryszewska E., Saniewski M. 1983. Auxin control of tulip stalk elongation in vitro. Sci. Hortic. 19: 153159. DOI: 10.1016/0304-4238(83)90056-0.

Geng X.M., Ii-Nagasuga K., Okubo H., Saniewski M. 2005a. Effects of TIBA on growth and flowering of non pre-cooled tulip bulbs. Acta Hort. 673: $207-$ 214.

Geng X.M., Okubo H., Saniewski M. 2005b. Cultivar and seasonal differences in the response of non precooled tulip bulbs to gibberellin, TIBA and root excision. J. Fac. Agr., Kyushu Univ. 50: 503-509.
Gilford J.McD., Rees A.R. 1973. Growth of tulip shoot. Sci. Hortic. 1: 143-156. DOI: 10.1016/03044238(73)90025-3.

Hanks G.R., Rees A.R. 1977. Stem elongation in tulip and narcissus: the influence of floral organs and growth regulators. New Phytol. 78: 579-591. DOI: 10.1111/j.1469-8137.1977.tb02161.x.

Hasenstein K.-H., Kaldewey H. 1984. Distribution and metabolism of IAA in relation to the growth of $\mathrm{He}$ lianthus hypocotyls. Bot. Gaz. 145: 163-169. DOI: 10.1086/337442.

McKay M.J., Ross J.J., Lawrence N.L., Cramp R.E., Beveridge C.A., Reid J.B. 1994. Control of internode length in Pisum sativum. Further evidence for the involvement of indole-3-acetic acid. Plant Physiol. 106: 1521-1526. DOI: 10.1104/pp.106.4.1521.

Miyamoto K., Kamisaka S. 1988. Stimulation of Pisum sativum epicotyl elongation by gibberellin and auxin. Different effects of two hormones on osmoregulation and cell walls. Physiol. Plant. 74: 457466. DOI: 10.1111/j.1399-3054.1988.tb02003.x.

Okubo H., Uemoto S. 1985. Changes in endogenous gibberellins and auxin activities during first internode elongation in tulip flower stalk. Plant Cell Physiol. 26: 709-719.

Op den Kelder P., Benschop M., de Hertogh A.A. 1971. Factors affecting floral stalk elongation of flowering tulips. J. Amer. Soc. Hort. Sci. 96: 603-605.

Ranwala A.P., Miller W.B. 2008. Gibberellin-mediated changes in carbohydrate metabolism during flower stalk elongation in tulips. Plant Growth Regul. 55: 241-248. DOI: 10.1007/s10725-008-9280-9.

Rapoport E.N., Heller K.E., Dayanandan P., Hebard F., Kaufman P. 1978. Role of indole-3-acetic acid and gibberellin in the control of internodal elongation in Avena stem segments. Plant Physiol. 62: 807811. DOI: 10.1104/pp.62.5.807.

Saniewski M., de Munk W.J. 1981. Hormonal control of shoot elongation in tulips. Sci. Hortic. 5: 363-372. DOI: 10.1016/0304-4238(81)90091-1.

Saniewski M., Góraj J., Węgrzynowicz-Lesiak E., Okubo H., Miyamoto K., Ueda J. 2010. Different growth of excised and intact fourth internode after removal of the flower bud in growing tulips: focus and auxin action. J. Fruit Ornam. Plant Res. 18: 297-308.

Saniewski M., Kawa L., Węgrzynowicz E. 1990. Influence of different concentrations of auxins and silver thiosulphate on stem growth and ethylene production in tulips. Bull. Polish Acad. Sci., Biol. Sci. 38: $1-12$. 
Saniewski M., Okubo H. 1997. Auxin induces stem elongation in nonprecooled and precooled derooted and rooted tulip bulbs. J. Fac. Agr., Kyushu Univ. 42: 53-61.

Saniewski M., Okubo H. 1998a. Effects of 2,3,5-triiodobenzoic acid (TIBA) on stem growth induced by indole-3-acetic acid (IAA) and naphthylacetic acid (NAA) in precooled rooted tulip bulbs. J. Fac. Agr., Kyushu Univ. 43: 11-23.

Saniewski M., Okubo H. 1998b. Inhibitory effect of naphthylphthalamic acid (NPA) on stem growth induced by auxin in precooled tulip bulbs. J. Fac. Agr., Kyushu Univ. 43: 59-66.

Saniewski M., Okubo H., Miyamoto K., Ueda J. 2011a. An inhibitor of auxin polar transport, 2,3,5-triiodobenzoic acid (TIBA), stimulates shoot growth and flowering of partially cooled tulips bulbs. Acta Hort. 886: 239-225.

Saniewski M., Okubo H., Miyamoto K., Oka M., Ueda J. 2011b. Stimulatory effect of 2,3,5-triiodobenzoic acid (TIBA) on shoot growth and flowering of partially cooled tulip (Tulipa gesneriana L.) bulbs. J. Fruit Ornam. Plant Res. 19: 149-160.

Saniewski M., Okubo H., Miyamoto K., Ueda J. 2012. Evidence for a role of auxin in the stem elongation of dark-grown tulips. Floriculture and Ornamental Biotechnology 6: 108-113.

Saniewski M., Okubo H., Puchalski J. 1999. Effect of morphactin on stem growth in relation to auxin in precooled rooted tulip bulbs. Acta Physiol. Plant. 21: 167-174. DOI: 10.1007/s11738-999-0072-2.

Ueda J., Góraj J., Węgrzynowicz-Lesiak E., Miyamoto K., Saniewski M. 2012. Morphactin substantially induced the fourth internode growth in decapitated tulips: relevance to endogenous levels of indole-3acetic acid. J. Fruit Ornam. Plant Res. 20: 161-171. DOI: 10.2478/v10290-012-0025-5.

Veen H. 1983. Silver thiosulphate: an experimental tool in plant science. Sci. Hortic. 20: 211-224. DOI: 10.1016/0304-4238(83)90001-8. 